\title{
PENGETAHUAN DAN PEKERJAAN IBU BERHUBUNGAN DENGAN PEMBERIAN MP-ASI DINI DI DESA NGAMPIN WILAYAH KERJA PUSKESMAS AMBARAWA
}

\author{
Ni Kadek Rika Ermera Yanthi ${ }^{1}$, Masruroh ${ }^{2}$ \\ E-mail: rikaermera@yahoo.com \\ ${ }^{1,2}$ DIV Kebidanan Fakultas Ilmu Kesehatan Universitas Ngudi Waluyo \\ Jln. Gedongsongo Candirejo Ungaran Kab. Semarang \\ Telp/Fax (024) 6925406
}

\begin{abstract}
Abstrak
Pemberian makanan pendamping ASI secara tepat sangat dipengaruhi perilaku ibu. Masih banyak ibu yang memberikan makanan pendamping ASI kurang dari 6 bulan. Penelitian ini bertujuan untuk mengetahui hubungan pengetahuan dan pekerjaan ibu terhadap pemberian MPASI dini di Desa Ngampin wilayah kerja Puskesmas Ambarawa. Metode penelitian yang digunakan adalah analitik korelasi dengan pendekatan cross sectional. Analisis bivariat dengan uji Chi square. Populasi penelitian ini adalah seluruh ibu menyusui yang memiliki bayi 6-12 bulan yang ada di Desa Ngampin wilayah Kerja Puskesmas Ambarawa sebanyak 43 orang. Sampel penelitian ini adalah 43 responden menggunakan Total sampling. Hasil penelitian menunjukkan sebagian besar ibu berpengetahuan cukup sebanyak 18 orang (41,9\%), ibu yang bekerja 26 orang $(60,5 \%)$ dan ibu yang memberikan MP-ASI dini 25 orang $(58,1 \%)$. Ada hubungan secara signifikan Pengetahuan dengan pemberian MP-ASI dini dengan p-value $0,008<\alpha(0,05)$. Adanya hubungan secara signifikan pekerjaan dengan pemberian MP-ASI dini dengan $p$-value $0,006<\alpha$ $(0,05)$.
\end{abstract}

\section{Kata Kunci $\quad$ : Pengetahuan, Pekerjaan, Pemberian MP-ASI dini}

\section{Pendahuluan}

Pemberian ASI secara ekslusif merupakan salah satu program pemerintah yang memiliki banyak manfaat bagi ibu dan bayi dalam meningkatkan kesehatan dan kesejahteraan ibu dan bayi.ASI merupakan makanan pertama,utama, dan terbaik bagi bayi, bersifat ilmiah. ASI eksklusif adalah bayi hanya diberi ASI selama 6 bulan tanpa tambahan makanan cairan lain, seperti susu formula, jeruk, madu, air teh, dan air putih, serta tanpa tambahan makanan padat, seperti pisang, bubur susu, biscuit, bubur nasi, dan nasi tim, kecuali vitamin, mineral, dan obat ${ }^{[1]}$.

Departermen Kesehatan Republik Indonesia menargetkan $80 \%$ pelaksanaan ASI ekslusif. Pada kenyataannya cakupan tersebut belum bisa tercapai. Persentase pemberian ASI ekslusif di indonesia pada tahun 2015 sebesar $55,7 \%{ }^{[2]}$

Di Jawa tengah pada tahun 2015 sebesar 61,6\%. Pada tahun 2015 cakupan
ASI ekslusif di wilayah kerja puskesmas Ambarawa hanya 85 bayi $(22,5 \%)$ dari total jumlah bayi sebanyak 377 yang merupakan cakupan terendah di Kabupaten Semarang. [4] Berdasarkan data jumlah bayi yang ASI ekslusif di Ambarawa yaitu Desa Tambak boyo merupakan cakupan ASI Ekslusif tertinggi tahun 2015 sebesar 35,9\% dan Desa Ngampin merupakan desa yang memiliki cakupan ASI Ekslusif terendah pada tahun 2015 yaitu sebesar $17,3 \%{ }^{[3]}$.

Pemerintah dalam menyukseskan program ASI ekslusif membuat UndangUndang Republik Indonesia Nomor 36 Tahun 2009 tentang Kesehatan pada pasal 128 disebutkan bahwa (1) Setiap bayi berhak mendapatkan air susu ibu eksklusif sejak dilahirkan selama 6 (enam) bulan, kecuali atas idikasi medis, (2) Selama pemberian air susu ibu, pihak keluarga, Pemerintah, Pemerintah Daerah, dan masyarakat harus mendukung ibu bayi secara penuh dengan penyediaan waktu dan fasilitas 
khusus, dan (3) Penyediaan fasilitas khusus sebagaimana dimaksud pada ayat (2) diadakan di tempat kerja dan tempat sarana umum ${ }^{[4]}$.

Makanan Pendamping ASI adalah makanan yang mengandung gizi yang diberikan pada anak usia 6-24 bulan guna memenuhi kebutuhan gizi. Pemberian makanan pendamping ASI secara tepat sangat dipengaruhi perilaku ibu yang memiliki bayi. Namun masih banyak ibu yang memberikan makanan pendamping ASI kurang dari 6 bulan ${ }^{[5]}$.

MPASI dianjurkan setelah bayi berumur enam bulan, karena pemberian makanan setelah enam bulan memberikan perlindungan besar dari berbagai penyakit. Jika memberikan makanan sebelum usia enam bulan, maka akan memberikan peluang bagi berbagai jenis kuman. Belum lagi bila tidak disajikan secara higienis. Hasil riset di indonesia menyatakan, bayi yang mendapat MP-ASI sebelum usia enam bulan lebih banyak terserang diare, sembelit, batuk-pilek dan panas dibanding dengan bayi yang mendapat MP-ASI setelah enam bulan ${ }^{[6]}$.

Pemberian MP-ASI terlalu dini yakni pada usia kurang dari 6 bulan adalah indikator bahwa ibu telah gagal memberikan ASI secara eksklusif, sehingga berdampak pada angka cakupan pemberian ASI eksklusif yang masih rendah. Pemberian MP-ASI dini erat kaitannya dengan keputusan yang dibuat oleh ibu. Pemberian MP-ASI terlalu dini banyak menimbulkan dampak bagi kesehatan bayi antara lain penyakit diare dan dapat menyebabkan kematian pada bayi. Hal ini disebabkan karena sistem pencernaan bayi belum siap menerima makanan selain ASI sehingga menimbulkan reaksi pada sistem pencernaan ${ }^{[7]}$.

Banyak orang tua menganggap bahwa kebutuhan nutrisi bayi tidak cukup hanya dengan ASI, sehingga bayi perlu dibantu dengan memberikan makanan pendamping ASI (MP-ASI). Pemberian makanan pendamping ASI (MP-ASI) berupa susu atau makanan padat yang lain pada kalangan orang tua sudah menjadi hal yang biasa, dengan berbagai alasan yang diberikan seperti ASI yang keluar sedikit, kesibukan ibu, kurangnya pengetahuan ibu tentang pemberian ASI, hemat waktu dan tergiur dengan kandungan susu formula yang ditawarkan $^{[7]}$.

Menurut Ginting, dkk, 2012 pemberian MP-ASI dini pada bayi Usia $<6$ bulan seharusnya tidak dilakukan karena bila makanan padat sudah mulai diberikan sebelum sistem pencernaan bayi siap untuk menerimanya, maka makanan tersebut tidak dapat dicerna dengan baik dan dapat menyebabkan reaksi yang tidak menyenangkan (gangguan pencernaan, timbulnya gas, dan konstipasi).

Banyak faktor yang mempengaruhi ibu dalam memberikan MP-ASI dini seperti pengetahuan, pendidikan, aktivitas, pendapatan, faktor petugas kesehatan, pekerjaan, paparan media dan dukungan keluarga ${ }^{[8]}$.

Faktor ibu bekerja seharusnya tidak menjadi masalah dalam hal memberikan ASI secara eksklusif meskipun cuti hamil atau melahirkan hanya tiga bulan yang mengakibatkan ibu belum selesai memberikan ASI eksklusif namun harus kembali bekerja. Dalam program pemberian ASI pada pekerja wanita diharapkan setiap perusahaan mendukung dengan cara memberikan waktu pada pekerja untuk memerah ASI dan memberikan ruangan pribadi bagi ibu menyusui ${ }^{[9]}$.

Berdasarkan hasil wawancara yang dilakukan kepada 10 orang ibu menyusui yang memiliki bayi usia 6-12 bulan di desa Ngampin wilayah kerja Puskesmas Ambarawa yang memberikan MP-ASI dini kepada bayinya terdapat 5 $(50 \%)$ ibu yang memberikan makanan pendamping ASI secara dini dengan alasan ASI tidak lancar sebanyak 2 (20\%) orang, ibu bekerja sebanyak 2 
(20\%) orang, dan sosial budaya $1(10 \%)$ orang dan $5 \quad(50 \%)$ ibu yang memberikan ASI ekslusif. Berdasarkan latar belakang diatas maka peneliti tertarik untuk mengetahui "Hubungan pengetahuan dan pekerjaan ibu terhadap pemberian MP-ASI dini pada bayi usia 6-12 bulan di Desa Ngampin". Tujuan penelitian ini adalah untuk mengetahui hubungan pengetahuan dan pekerjaan ibu terhadap pemberian MP-ASI dini di Desa Ngampin Wilayah Kerja Puskesmas Ambarawa.

\section{Metode Penelitian}

Jenis penelitian yang digunakan adalah analitik kolerasi dengan pendekatan secara cross sectional. Metode pengumpulan data dengan kuesioner, analisis univariat dengan distribusi frekuensi dan analisis bivariat dengan uji Chi square.Populasi dalam penelitian ini adalah seluruh ibu menyusui yang memiliki bayi 6-12 bulan yang ada di Desa Ngampin wilayah Kerja Puskesmas Ambarawa pada tahun 2017 periode Mei, yaitu yang berjumlah 43 orang. Sampel dalam penelitian ini adalah ibu menyusui yang memiliki bayi usia 6-12 bulan. Pengambilan sampel penelitian ini menggunakan teknik Total sampling

\section{Hasil dan Pembahasan}

\section{Distribusi Frekuensi Berdasarkan}

Pengetahuan ibu terhadap MP-ASI dini di Desa Ngampin wilayah Kerja Puskesmas Ambarawa.

Berdasarkan hasil pada table 1 dapat diketahui bahwa pengetahuan ibu menyusui tentang MP-ASI di Desa Ngampin wilayah Kerja Puskesmas Ambarawa, sebagian besar dalam kategori cukup, yaitu sejumlah 18 orang $(41,9 \%)$.

Tabel 1: Distribusi Frekuensi Berdasarkan Pengetahuan Ibu Terhadap MP-Asi Dini

Pengetahuan $\quad$ Frekuensi $\quad$ Persentase (\%)

\begin{tabular}{lcc}
\hline Kurang & 12 & 27,9 \\
Cukup & 18 & 41,9 \\
Baik & 13 & 30,2 \\
\hline Jumlah & 43 & 100,0 \\
\hline
\end{tabular}

Pengetahuan ibu adalah salah satu faktor penting dalam pemberian makanan tambahan pada bayi karena dengan pengetahuan yang baik, ibu tahu kapan waktu pemberian makanan yang tepat. Pengetahuan dapat diperoleh dari informasi yang disampaikan orang lain, media cetak, media elektronik, atau penyuluhan-penyuluhan ${ }^{[10]}$.

Pendidikan adalah kegiatan atau proses belajar yang terjadi dimana saja, kapan saja, dan oleh siapa saja. Seseorang dapat dikatakan belajar apa bila didalam dirinya terjadi perubahan dari tidak tahu menjadi tahu, dari tidak mengerjakan menjadi dapat mengerjakan sesuatu.

Hal ini dibuktikan dari hasil penelitian Kusmiyati (2014) yang menyatakan bahwa pendidikan dapat mempengaruhi tingkat pengetahuan seseorang, semakin tinggi tingkat pendidikan seseorang makin mudah menerima informasi, sehingga makin baik pengetahuannya, akan tetapi seseorang yang berpendidikan rendah belum tentu berpengetahuan rendah. Dilihat dari jawaban kuesioner tentang pengetahuan MP-ASI yang di berikan kepada 43 orang responden pertanyaan yang paling sedikit dijawab benar adalah pertanyaan tentang waktu pemberian MP-ASI sebanyak 14 orang (32,6\%) dimana pertanyaanya adalah "Menurut anda waktu pemberian makanan pendamping ASI yang benar yaitu diberikan sebelum bayi berumur 6 bulan". Hal ini disebabkan bahwa ibu masih beranggapan bahwa ASI ekslusif diberikan sampai umur 4 bulan sehingga dapat mempengaruhi waktu pemberian MP-ASI ${ }^{(11)}$.

\section{Distribusi Frekuensi Berdasarkan Pekerjaan pada Ibu Menyusui yang Memiliki Bayi 6-12 Bulan di Desa}


Ngampin wilayah Kerja Puskesmas

Tabel 2: Distribusi Frekuensi Berdasarkan Pekerjaan pada Ibu Menyusui yang Memiliki Bayi 6-12 Bulan

\begin{tabular}{lcc}
\hline \multicolumn{1}{c}{ Pekerjaan } & Frekuensi & $\begin{array}{c}\text { Persentase } \\
(\%)\end{array}$ \\
\hline Bekerja & 26 & 60,5 \\
Tidak Bekerja & 17 & 39,5 \\
\hline Jumlah & 43 & 100,0 \\
\hline
\end{tabular}

Hasil pada tabel 2 dapat diketahui bahwa sebagian besar ibu menyusui di Desa Ngampin wilayah Kerja Puskesmas Ambarawa, merupakan ibu yang bekerja, yaitu sejumlah 26 orang $(60,5 \%)$.

Ibu yang bekerja jenis pekerjaannya bervariasi, namun kebanyakan ibu bekerja sebagai karyawan swasta dan buruh pabrik. Sebagai buruh pabrik ibu bekerja di bidang tenaga produksi di pabrik-pabrik sekitar. Jam kerja di pabrik rata-rata dimulai dari jam 07.00 WIB sampai jam 17.00 WIB. Sebagai pekerja di luar rumah, tentunya akan terjadi pengurangan waktu ibu berada di rumah. Ibu yang bekerja memiliki intensitas mengurus rumah tangga dan anak sangat kurang. Sebagian besar ibu yang bekerja menitipkan anak kesanak keluarga atau pengasuh, sehingga target ASI ekslusif tidak terpenuhi karena ibu merasa kelelahan, karena harus bekerja dan mengurus rumah tangga.

Beberapa ibu yang beranggapan memerah ASI terlalu banyak menghabiskan waktu dan sarana prasarana tidak mendukung. Waktu istirahat pada ibu pekerja pabrik 30 menit sampai 60 menit sedangkan ASI harus diperah setiap 2 jam sekali dan pakbir mempunyai target-target pekerjaan yang harus diselesaikan sehingga ibu tidak bisa semena-mena istirahat setiap 2 jam sekali untuk memerah ASInya. Ketika bayi diasuh oleh keluarga atau pengasuh saat bayi rewel keluarga beranggapan bahwa bayi lapar sehingga bayi diberikan makanan pendamping ASI sebelum usia 6 bulan.
Menurut kamus besar Indonesia, menyatakan bahwa pekerjaan adalah barang yang diperbuat atau dikerjakan. Pekerjaan adalah kegiatan rutin seharihari, yang dilakukan oleh seseorang dengan maksud memperoleh penghasilan ${ }^{[11]}$.

Hal ini sejalan dengan penelitian Sri (2008) yang menyatakan bahwa beberapa hambatan yang dirasakan ibu bekerja dalam pratik menyusui secara ekslusif adalah jarak rumah yang jauh, tidak ada fasilitas ditempat kerja agar ibu dapat menyusui bayinya.

Sedangkan ibu yang tidak bekerja sejumlah 17 orang $(39,5 \%)$, karakteristik ibu tidak bekerja yang ada di desa ngampin wilayah kerja puskesmas Ambarawa adalah sebagai ibu rumah tangga yang banyak memiliki waktu luang untuk merawat dan memberikan ASI pada anaknya. Ibu yang dikatakan tidak bekerja, ibu yang hanya berada di rumah yang fokus mengerjakan pekerjaan rumah dan mengurus anak. Menurut Kamus Besar Bahasa Indonesia, ibu rumah tangga dapat diartikan sebagai seorang wanita yang mengatur penyelenggaraan berbagai macam pekerjaan rumah tangga, atau ibu rumah tangga merupakan seorang istri (ibu) yang hanya mengurusi berbagai pekerjaan dalam rumah tangga (tidak bekerja di kantor) ${ }^{[12]}$.

\section{Distribusi Frekuensi Berdasarkan Pemberian MP-ASI Dini pada Ibu Menyusui yang Memiliki Bayi 6-12 Bulan di Desa Ngampin wilayah Kerja Puskesmas Ambarawa \\ Berdasarkan tabel .3 dapat diketahui bahwa sebagian besar ibu menyusui di Desa Ngampin memberikan MP-ASI dini pada bayinya, yaitu sejumlah 25 orang $(58,1 \%)$.}

Tabel 3: Distribusi Frekuensi Berdasarkan Pemberian MP-ASI Dini pada Ibu Menyusui yang Memiliki Bayi 6-12 Bulan 


\begin{tabular}{lcc}
\hline $\begin{array}{c}\text { Pemberian MP-ASI } \\
\text { Dini }\end{array}$ & $\begin{array}{c}\text { Frekuens } \\
\text { i }\end{array}$ & $\begin{array}{c}\text { Persentase } \\
(\%)\end{array}$ \\
\hline Diberikan $\quad$ MP-ASI & & \\
Dini & 25 & 58,1 \\
Tidak Diberikan & 18 & 41,9 \\
MP-ASI Dini & & \\
\hline Jumlah & 43 & 100,0 \\
\hline
\end{tabular}

Makanan pendamping ASI (MP-ASI) adalah makanan tambahan yang diberikan kepada bayi setelah bayi berusia 6 bulan sampai bayi berusia 24 bulan $^{[13]}$.

Menurut Muyosaro (2013) akibat dari pemberian makanan padat yang terlalu dini kepada bayi (dibawah 6 bulan) yaitu konsumsi ASI bayi menurun sehingga produksi ASI akan berkurang, bayi rentan terhadap serangan penyakit karena saat itu asupan zat pelindung yang berasal dari ASI berkurang, bayi beresiko terkena diare, lambung bayi akan terpenuhi oleh makanan yang mempunyai kandungan zat gisi yang jauh lebih rendah dibandingkan dengan $\mathrm{ASI}^{[14]}$.

Kenyataannya dilapangan masih banyak ibu yang memberikan MP-ASI pada bayi sebelum mencapai usia 6 bulan. Hasil penelitian menunjukkan bahwa sebagian besar ibu menyusui di Desa Ngampin wilayah Puskesmas Ambarawa, memberikan MP-ASI dini pada bayinya, yaitu sejumlah 25 orang $(58,1 \%)$ sedangkan yang tidak memberikan MP-ASI dini sejumlah 18 orang (41,9\%). Pemberian MP-ASI dini tinggi dimungkinkan ada beberapa faktor penebab diantaranya rasa takut bahwa ASI yang mereka hasilkan tidak cukup atau kualitasnya buruk, keterlambatan memulai pemberian ASI dan praktek membuang klostrum, teknik pemberian ASI yang salah, kebiasaan yang keliru bahwa bayi memerlukan cairan tambahan, dukungan yang kurang dari pelayanan kesehatan, dan gencarnya promosi susu formula.

Hal ini sesuai dengan penelitian yang dilakukan Afriyani, dkk (2016) tentang faktor-faktor yang berhubungan dengan pemberian MP-ASI pada bayi usia 0-6 bulan di BPM Nurtila di Palembang bahwa ada hubungan antara tradisi dengan pemberian MP-ASI pada bayi 06 bulan. Hal ini menyatakan bahwa ibu yang mengikuti tradisi memiliki kecendrungan 16,000 kali lebih besar memberikan MP-ASI pada bayi usi 0-6 bulan dibandingkan ibu yang tidak mengikuti tradisi ${ }^{[15]}$.

Kerja Puskesmas Ambarawa, memberikan MP-ASI dini pada bayinya, yaitu sejumlah 25 orang $(58,1 \%)$ sedangkan yang tidak memberikan MPASI dini sejumlah 18 orang (41,9\%). Pemberian MP-ASI dini tinggi dimungkinkan ada beberapa faktor penebab diantaranya rasa takut bahwa ASI yang mereka hasilkan tidak cukup atau kualitasnya buruk, keterlambatan memulai pemberian ASI dan praktek membuang klostrum, teknik menyusui yang salah.

\section{Hubungan Pengetahuan dengan Pemberian MP-ASI Dini pada ibu Menyusui yang Memiliki Bayi 6-12 Bulan di Desa Ngampin wilayah Kerja Puskesmas Ambarawa}

Tabel 4: Hubungan Pengetahuan dengan Pemberian MP-ASI Dini pada ibu Menyusui yang Memiliki Bayi 6-12 Bulan

\begin{tabular}{|c|c|c|c|c|c|c|c|c|}
\hline \multirow{3}{*}{$\begin{array}{l}\text { Pengetahu } \\
\text { an }\end{array}$} & \multicolumn{6}{|c|}{ Pemberian MP-ASI Dini } & \multirow{3}{*}{$\chi^{2}$} & \multirow{3}{*}{$\begin{array}{c}\text { p- } \\
\text { valu } \\
\text { e }\end{array}$} \\
\hline & \multicolumn{2}{|c|}{$\begin{array}{c}\text { Diberika } \\
\mathrm{n}\end{array}$} & \multicolumn{2}{|c|}{$\begin{array}{c}\text { Tidak } \\
\text { Diberika } \\
\mathrm{n}\end{array}$} & \multicolumn{2}{|c|}{ Total } & & \\
\hline & $\mathrm{f}$ & $\%$ & $\mathrm{f}$ & $\%$ & $\mathrm{~F}$ & $\%$ & & \\
\hline Kurang & 11 & 91,7 & 1 & 8,3 & 12 & 100 & 9,593 & 0,00 \\
\hline Cukup & 10 & 55,6 & 8 & 44,4 & 18 & 100 & & 8 \\
\hline Baik & 4 & 30,8 & 9 & 69,2 & 13 & 100 & & \\
\hline Total & 25 & 58,1 & 18 & 41,9 & 43 & 100 & & \\
\hline
\end{tabular}

Hasil uji Chi Square diperoleh Chi Square hitung sebesar 9,593 dengan pvalue 0,008 . Karena p-value $0,008<\alpha$ $(0,05)$ maka ada hubungan secara signifikan Pengetahuan dengan pemberian MP-ASI dini pada ibu menyusui yang memiliki bayi 6-12 bulan 
di Desa Ngampin wilayah Kerja Puskesmas Ambarawa.

Pengetahuan merupakan hasil dari tahu, dan ini terjadi setelah orang melakukan penginderaan terhadap suatu obyek tertentu. Pengetahuan terjadi setelah orang melakukan penginderaan melalui, panca indera, penglihatan, pendengaran, penciuman, rasa dan raba. Sebagian besar pengetahuan manusia diperoleh melalui mata dan telinga. Pengetahuan atau kognitif merupakan domain yang sangat penting untuk terbentuknya tindakan seseorang ${ }^{[1]}$.

Hasil penelitian menunjukkan bahwa dari 43 orang responden ibu menyusui yang memiliki bayi 6-12 bulan di Desa Ngampin wilayah Kerja Puskesmas Ambarawa 12 orang ibu dengan pengetahuan kurang. Dari 12 orang tersebut, 11 orang $(91,7 \%)$ yang memberikan MP-ASI dini, ini disebabkan karena kurangnya pengetahuan ibu tentang MP-ASI. Kurangnya pengetahuan ibu tentang MPASI dapat menyebabkan pemberian MPASI dini pada bayi kurang dari 6 bulan, karena ibu tidak paham akan waktu pemberian makanan pendamping ASI yang tepat. Hal ini sesuai dengan penelitian yang dilakukan Meike, dkk (2014) bahwa responden yang memiliki pengetahuan kurang akan berpeluang melakukan pemberian MP-ASI dini sebesar 2,951 kali lebih tinggi dibanding dengan yang memiliki pengetahuan baik $^{[16]}$.

Hal ini sejalan dengan penelitian Geelhoed, et all (2010) di Mozambique menyatakan bahwa rendahnya pengetahuan dapat mempengaruhi pemberian MP-ASI dini pada bayi sebelum 6 bulan, dan ini juga dapat disebabkan karena sikap, dukungan keluarga dan budaya ${ }^{[17]}$.

Hal ini didukung juga oleh penelitian Kingsley, et all (2011) di Nigeria mengatakan bahwa tingkat pengetahuan rendah memiliki resiko lebih besar untuk memberikan MP-ASI dini kepada bayi $^{[18]}$.

Hasil penelitian menunjukkan bahwa dari 43 orang responden ibu menyusui yang memiliki bayi 6-12 bulan di Desa Ngampin wilayah Kerja Puskesmas Ambarawa ibu dengan pengetahuan cukup sebanyak 18 orang. Dari 18 orang, yang memberikan MP-ASI dini pada bayinya sejumlah 10 orang $(55,6 \%)$. Hal ini sejalan dengan penelitian yang di lakukan Adam, dkk (2014) bahwa ada hubungan yang signifikan antara pengetahuan dengan pemberian MP-ASI karena hambatan utama tercapainya ASI eksklusif dan pemanfaatan MP-ASI yang benar karena kurangnya pengetahuan yang benar tentang ASI eksklusif dan MP-ASI pada para $\mathrm{ibu}^{[19]}$.

Sedangkan yang berpengetahuan cukup, yang tidak memberikan MP-ASI dini sejumlah 8 orang $(44,4 \%)$. Walaupun ibu berpengetahuan cukup tentang pemberian MP-ASI dan waktu pemberian MP-ASI yang tepat, namun ibu menerapkan apa yang dia tahu tentang MP-ASI dan mengikuti apa yang dikatakan oleh tenaga kesehatan. Hal ini sejalan dengan penelitian yang dilakukan Kodyah (2009) tentang Hubungan Tingkat Pengetahuan Ibu dengan Pemberian Makanan Pendamping ASI (MP-ASI) di Desa Jetirejo Kecamatan Jumapolo bahwa ada hubungan yang sangat cukup bermakna antara variabel tingkat pengetahuan ibu dengan pemberian makanan pendamping $\operatorname{ASI}^{[20]}$.

Hasil penelitian menunjukkan bahwa dari 43 orang responden ibu menyusui yang memiliki bayi 6-12 bulan di Desa Ngampin wilayah Kerja Puskesmas Ambarawa ibu dengan pengetahuan baik sebanyak 13 orang. Dari 13 orang tersebut, yang tidak memberikan MPASI dini pada bayinya sejumlah 9 orang $(69,2 \%)$ hal ini disebabkan karena ibu yang berpengetahuan baik tentang MPASI dan paham akan waktu yang tepat dalam pemberian MP-ASI tidak akan memberikan MP-ASI dini pada bayinya. 
Secara teori pengetahuan akan menentukan perilaku seseorang. Secara rasional seorang ibu yang memiliki pengetahuan tinggi tentu akan berpikir lebih dalam bertindak, dia akan memperhatikan akibat yang akan diterima bila dia bertindak sembarangan. Dalam menjaga kesehatan bayinya terutama dalam pemberian makanan pendamping ASI yang tepat seorang ibu dituntut memiliki pengetahuan yang tinggi sehingga pemberian makanan pendamping ASI terlalu dini dapat dicegah $^{[11]}$.

Ibu dengan pengetahuan baik namun memberikan MP-ASI dini sejumlah 4 orang $(30,8 \%)$. Hal ini dapat terjadi karena walaupun tingkat pengetahuan ibu baik tentang MP-ASI tetapi dipengaruhi oleh beberapa faktor diantaranya faktor internal yaitu tingkat pengetahuan dan sikap ibu. Faktor eksternal yang dapat mempengaruhi pemberian MP-ASI dini di usia bayi $<6$ bulan adalah dukungan keluarga, peran petugas, budaya setempat, tradisi keluarga serta anggapan bahwa ASI saja tidak cukup untuk memenuhi kebutuhan bayi.

\section{Hubungan Pekerjaan dengan} Pemberian MP-ASI Dini pada Ibu Menyusui yang Memiliki Bayi 6-12 Bulan di Desa Ngampin wilayah Kerja Puskesmas Ambarawa

Berdasarkan Hasil uji Chi Square (continuity correction) diperoleh p-value 0,006 . Karena p-value $0,006<\alpha(0,05)$ maka Ho ditolak, dan disimpulkan bahwa ada hubungan secara signifikan pekerjaan dengan pemberian MP-ASI dini pada ibu menyusui yang memiliki bayi 6-12 bulan di Desa Ngampin wilayah Kerja Puskesmas Ambarawa.

Tabel 4: Hubungan Pengetahuan dengan Pemberian MP-ASI Dini pada ibu Menyusui yang Memiliki Bayi 6-12 Bulan

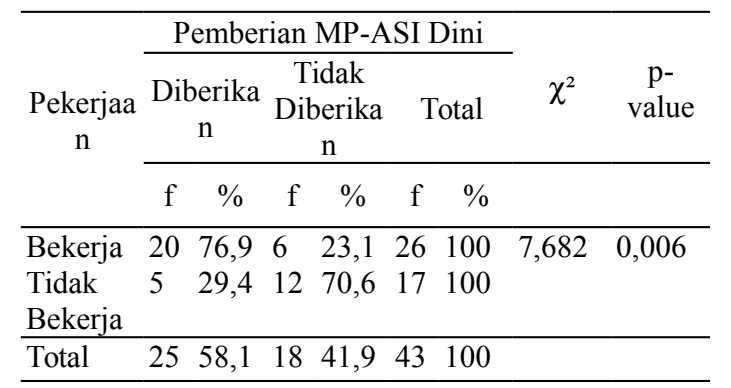

Hasil penelitian menunjukkan bahwa dari 43 orang responden ibu menyusui yang memiliki bayi 6-12 bulan di Desa Ngampin wilayah Kerja Puskesmas Ambarawa sebanyak 26 orang sebagian besar memberikan MP-ASI dini pada bayinya sejumlah 20 orang $(76,9 \%)$, ini disebabkan kurangnya waktu yang dimiliki ibu pekerja dalam pemberian ASI.

Kondisi ini semakin diperburuk dengan UU No. laktasi. 13 Tahun 2003 tentang Ketenagakerjaan yang berlaku di Indonesia. Pasal 82 dalam UU ini secara eksplisit memuat,"Pekerja/ buruh perempuan berhak memperoleh istirahat selama 1,5 (satu setengah) bulan sebelum melahirkan anak dan 1,5 (satu setengah) bulan sesudah melahirkan menurut perhitungan dokter kandungan atau bidan". Hal ini jelas tidak sejalan dengan rekomendasi World Health Organization yang mensyaratkan pada bayi usia $<6$ bulan harus diberikan ASI ekslusif.

Ibu yang bekerja yang tidak memberikan MP-ASI dini sebanyak 6 orang $(23,1 \%)$. Kemampuan seseorang dalam melakukan pekerjaan berbeda dengan orang lain, kemampuan tersebut dapat berkembang karena pendidikan dan pengalaman sehingga lingkungan pekerjaan dapat menjadikan seseorang memperoleh pengalaman serta pengetahuan baik secara langsung maupun tidak langsung ${ }^{[1]}$.

Hasil penelitian menunjukkan bahwa dari 43 orang responden ibu menyusui yang memiliki bayi 6-12 bulan di Desa Ngampin wilayah Kerja Puskesmas Ambarawa ibu yang tidak bekerja sebanyak 17 orang sebagian besar tidak memberikan MP-ASI dini pada bayinya 
sejumlah 12 orang $(70,6 \%)$. Hal ini dikarenakan ibu yang tidak bekerja banyak memiliki waktu untuk menyusui anaknya bahkan banyak mempunyai waktu untuk datang ke posyandu setiap bulan dan mendengarkan penyuluhan terkait kesehatan anak. Ini berarti ibu rumah tangga memiliki ketersediaan waktu yang lebih banyak untuk memberikan ASI ekslusif ${ }^{10]}$.

Sedangkan ibu yang tidak bekerja namun memberikan MP-ASI dini sebanyak 5 orang $(29,4 \%)$. Ibu yang tidak bekerja memberikan MP-ASI dini pada bayinya disebabkan oleh budaya yang diturunkan dari mertua.

Ada beberapa faktor yang dapat memperngaruhi diantaranya pendidikan, tenaga kesehatan, lingkungan dan dukungan keluarga. Selain itu faktor lain yang mempengaruhi yaitu adanya acuan atau referensi yang kurang tepat tantang MP-ASI dari seseorang atau dari pribadi yang dipercayai seperti mertua, yang pola pikirnya masih dipengaruhi oleh sosial budaya dan pengalaman pribadi yang berpengaruh terhadap penerimaan seseorang dalam kehidupannya seharihari. Pengalaman bahwa anak - anak pada jaman dahulu diberikan MP-ASI sebelum usia 6 bulan tidak apa - apa menjadi salah satu alasan pemberian MP-ASI dini ${ }^{[11]}$.

\section{Kesimpulan}

Ada hubunga pengetahuan dengan pemberian MP-ASI dini pada ibu menyusui yang memiliki bayi 6-12 bulan di Desa Ngampin Wilayah kerja Puskesmas Ambarawa dan ada hubungan Pekerjaan dengan Pemberian MP-ASI Dini pada Ibu Menyusui yang Memiliki Bayi 6-12 Bulan di Desa Ngampin wilayah Kerja Puskesmas Ambarawa.

\section{Daftar Pustaka}

[1] Prasetiono Dwi Sunar. 2009. Buku Pintar ASI Ekslusif. Yogyakarta : Diva Press
[2] Profil Kesehatan Indonesia tahun 2015. Profil Kesehatan Indonesia tahun 2015. Online diakses tanggal 12 Desember 2016 pukul 20.00 WIB

[3] Profil Kesehatan Kabupaten Semarang tahun 2015. Profil Kesehatan Jawa Tengah tahun 2015. Online diakses tanggal 2 Januari 2017 pukul 09.30 WIB

[4] Depkes RI. 2010. Profil Kesehatan Indonesia Tahun 2010. Online diakses tanggal 20 Januari 2017 pukul 13.00 WIB

[5] Utami Roesli. 2012. Panduan Inisiasi Menyusui Dini. Jakarta : Pustaka Bunda

[6] Nirwana Ade Benih. 2014. ASI dan Susu Formula Kandungan dan Manfaat ASI dan Susu Formula. Yogyakarta : Nuha Medika

[7] Anditia Resty. 2010. 101 Hal Penting Merawat Bayi yang Wajib Anda Ketahui. Jogjakarta : ARBuzz Media Group

[8] Setiawati Nita. 2015. Hubungan Dukungan Keluarga dengan Pemberian MP-ASI (Makanan Pendamping Air Susu Ibu) Dini di Desa Beji Kecamatan Andong Kabupaten Boyolali. Skripsi. STIKES Ngudi Waluyo

[9] Hendrawan Desy. 2014. Makan dan Tidur Bayi. Jakarta Barat : PT Media Pustaka Phoenix

[10] Aryani. 2008. Makanan Pendamping ASI (MPASI). Diakses 01 Juli 2017.

[11] Notoatmodjo, S. 2007. Pendidikan dan Perilaku Kesehatan. Jakarta : Rineka Cipta.

[12] Kumiyati, dkk. 2014. Hubungan Pengetahuan, Pendidikan dan Pekerjaan Ibu dengan Pemberian Makanan Pendamping ASI (MPASI) Pada Bayi di Puskesmas Bahu Kecamatan Malalayang Kota Manado. Jurnal Ilmu Kebidanan. Vol. 2, No. 2. 
http://journalilmubidan.or.id.

Diakses pada tanggal 5 juli 2017

[13] Asih dan Risneni. 2016. Buku Ajar Asuhan Kebidanan Nifas dan Menyusui. Jakarta : CV. Trans Info Medika

[14] Muyosaro Puspitarini. 2013. Buku Pintar Merawat Bayi. Jakarta Timur: Dunia Sehat

[15] Afriyani Rahmalla, dkk. 2016. Faktor-faktor yang Berhubungan dengan Pemberian MP-ASI pada Bayi Usia 0-6 Bulan di BPM Nurtila Palembang. http://faktor-faktoyang-berhubungan-denganpemberianMP-ASIjurnal.go.id. Diakses pada tanggal 7 juli 2017

[16] Meike Ibrahim, dkk. 2014. Hubungan antara Karakteristik Ibu dan Prilaku Ibu dengan Riwayat Pemberian Makanan Pendamping ASI (MP-ASI) Dini di Wilayah Puskesmas Atinggola Kecamatan Antinggola Kabupaten Gorontalo Utara.

http://www.univsamratulang.ic.id. Dialses pada tanggal 2 juli 2017

[17] Geelhoed, MD, Phd, et all. 2010. Knowledge, beliefs, and Practices regarding exclusive breastfeeding of infats younger than 6 months in Mozambique. Avalable:

http://journals.sagepub.com.

Diakses pada tanggal 12 juli 2017

[18] Kingsley E Agho, et all. 2011. Determinants of exclusive breastfeeding in Nigraria. Avalable: http://journalpregnancyandchildbirt h.com diakses pada tanggal 11 juli 2017

[19] Adam, dkk. 2014. Hubungan Antara Pengetahuan, Pendidikan dan Pekerjaan Ibu dengan Pemberian Makanan Pendampng ASI. http://skripsikebidanan.go.id.

Diakses pada tanggal 1 Juli 2017

[20] Kodyah Nurul. 2009. Hubungan Tingkat Pengetahuan Ibu Dengan Pemberian makanan Pendamping

\author{
ASI (MP-ASI) di Desa Jatirejo \\ Kecamatan \\ Jumpolo. \\ http://skripsikebidanan.go.id.
}


